\title{
Analiza przemieszczeń geometrycznych i kinematycznych krajowych pojazdów tramwajowych na torze prostym oraz na łuku o minimalnym promieniu
}

\begin{abstract}
Artykut jest poświęcony studium położenia pojazdu tramwajowego $w$ torze prostym oraz na tuku o minimalnym promieniu z uwzględnieniem najniekorzystniejszych przemieszczeń geometrycznych i kinematycznych, które wptywaja na ostateczny zarys pojazdu szynowego. Dokonano szczególowej analizy wybranych czynników, majacych wplyw na zwężenia wewnętrzne i zewnętrzne oraz podano możliwości korekty wzorów, celem uzyskania większej przestrzeni dla nadwozia tramwaju bez pogorszenia bezpiecznej jazdy.

Artykut powstat w ramach projektu badawczego $n r N 509$ 03531/2367 finansowanego przez

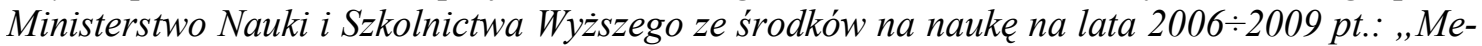
todyka wyznaczania kinematycznego zapotrzebowania przestrzeni oraz luzów bezpieczeństwa dla pojazdów tramwajowych, celem ustalenia optymalnego zarysu pojazdu”
\end{abstract}

\section{Wstęp}

Obecnie obowiązująca norma PN-K-92008 [10] wraz z PN-K-92008/Ap1 [11] formułuje wzory na zwężenia wewnętrzne $E_{i}$ oraz zewnętrzne $E_{a}$, odejmowane od zarysu odniesienia skrajni kinematycznej, celem ustalenia dopuszczalnego zarysu dla wózkowych oraz dwuosiowych pojazdów tramwajowych. Wzory te wynikają z najbardziej niekorzystnych ustawień geometrycznych na różnych odcinkach toru oraz przemieszczeń kinematycznych pojazdu ( dynamika układu tor-pojazd ). Analizę tych wzorów przeprowadzono w [4]. Wzory na zwężenia wyprowadzono w oparciu o założenie, że wszystkie czynniki w nich uwzględnione występują jednocześnie $\mathrm{z}$ takim samym prawdopodobieństwem i działają $\mathrm{w}$ tym samym kierunku. Wychodzi się tutaj z założenia, że tak skonstruowany pojazd może być eksploatowany z maksymalnym bezpieczeństwem lub inaczej, zarys pojazdu musi być tak skonstruowany, aby w żadnym $\mathrm{z}$ dopuszczalnych stanów eksploatacyjnych nie mogło dochodzić do niebezpieczeństwa zetknięcia się pojazdów. Przy obliczaniu skrajni uwzględnia się istotne właściwości pojazdu i toru. Kolejnym czynnikiem, który uwzględnia się w wyznaczaniu dopuszczalnego zarysu pojaz$\mathrm{du}$, jest maksymalne przemieszczenie pojazdu $\mathrm{H}_{\mathrm{i}} \mathrm{w}$ dół, wynikające ze zużycia kół zestawów kołowych, sprężystego ugięcia ich elementów elastycznych, ugięcia usprężynowania (statycznego i dynamicznego), przemieszczenia pionowego pojazdu w wyniku wjazdu na pionowy tor wklęsły lub wypukły. Jeśli pojazd spełnia pod względem dopuszczalnego zarysu wymagania PN-K-92008 [10] oraz PN-K-92008/Ap1 [11], wówczas żaden jego punkt nie powinien podczas eksploatacji w najbardziej niekorzystnych warunkach wejść w kolizję z urządzeniami stałymi umieszczony$\mathrm{mi}$ poza zarysem określonym $\mathrm{w}$ normie $\mathrm{PN}-\mathrm{K}-$ 92009:1998 [12].
Jak wynika z [6,7 i 8] przy wyznaczaniu zwężeń wewnętrznych oraz zewnętrznych istotnym czynnikiem jest analiza najbardziej niekorzystnych położeń pojazdu tramwajowego w torze:

- położenie skrajnie wewnętrzne w huku ( pojazd nabiega osiami prowadzącymi na szynę wewnętrzną toru- niem. Sehnenstellung-rys.3)

- położenie skrajnie zewnętrzne w łuku (pojazd nabiega osiami prowadzącymi na szynę zewnętrzną toru- niem. Spießgangstellung)

- położenie z przodu swobodne w łuku ( niem. Freilauf des vorderen Radsatzes)

- położenie z tyłu swobodne w łuku ( niem. Freilauf des hinteren Radsatzes)

- położenie narożnikowe w torze prostym ( rys.1) i w łuku ( rys.2).

2. Położenia pojazdów tramwajowych $w$ torze stanowiące bazę do ustalania zwężeń wewnętrznych oraz zewnętrznych

Przy wyznaczaniu zwężeń wewnętrznych $\mathrm{E}_{\mathrm{i}} \mathrm{i}$ zewnętrznych $E_{a}$ na torze prostym najbardziej niekorzystnym położeniem ze wszystkich możliwych w eksploatacii jest położenie narożnikowe (rys.1)

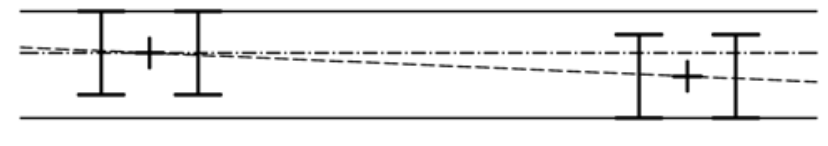

kierunek jazdy

Rys.1. Położenie narożnikowe konwencjonalnego pojazdu tramwajowego wózkowego w torze prostym

Przy wyznaczaniu zwężeń wewnętrznych $\mathrm{E}_{\mathrm{i}} \mathrm{i}$ zewnętrznych $E_{a}$ na łuku najbardziej niekorzystnym położeniem jest odpowiednio położenie skrajnie wewnętrzne (rys.3) oraz narożnikowe (rys.2). 


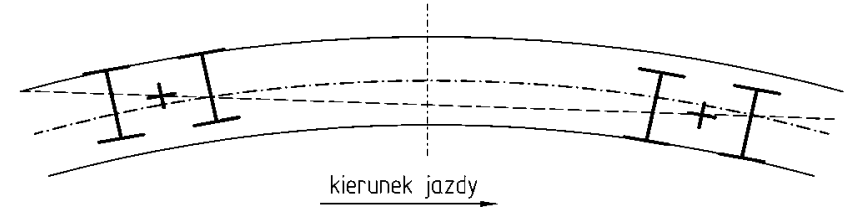

Rys.2. Położenie narożnikowe konwencjonalnego pojazdu tramwajowego wózkowego w łuku toru

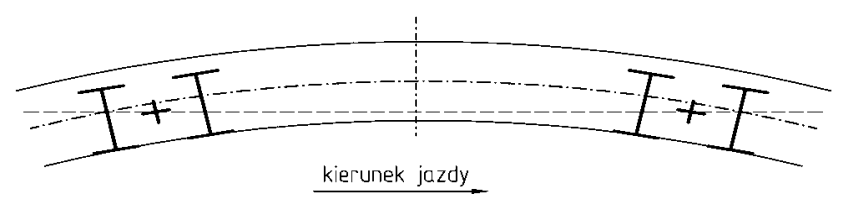

Rys.3.Położenie skrajnie wewnętrzne konwencjonalnego pojazdu tramwajowego wózkowego w łuku toru

Częstym analizowanym przypadkiem, świadczącym o bezpiecznej eksploatacji, jest mijanie się dwóch tramwajów podczas ustawienia narożnikowego na torze prostym oraz na łuku.

Przy analizie najbardziej niekorzystnego ustawienia pojazdu w torze należy również wziąć pod uwagę wszystkie możliwe ustawienia zestawu kołowego w torze, które są przedstawione na rys.4 [3]. Idealnym ustawieniem zestawu kołowego w łuku toru jest tzw. ustawienie radialne-rys.4b ( niem. ,radiale Einstellung"), czyli zestaw kołowy toczy się w kierunku łuku toru bez nabiegania na szynę wewnętrzną oraz zewnętrzną. Bardzo często występują jednak dwa inne ustawienia zestawu kołowego w torze ( tzn. „pozaradialne" oraz ", przedradialne" z niem. odpowiednio „überrradiale Stellung” i ,unterradiale Stellung”rys.4a i 4c). Podczas ustawienia „przedradialnego" występuje nabieganie zestawu kołowego na szynę zewnętrzną łuku toru pod kątem $\psi$ ( niem. „Anlaufwinkel” lub „Anschneidwinkel”) [3]. W przypadku ustawienia „pozaradialnego" występuje nabieganie zestawu kołowego na szynę wewnętrzną łuku toru. Radialne lub quasi-radialne ustawienie się zestawu kołowego sprzyja bardziej ustawieniu narożnikowemu lub skrajnie wewnętrznemu na łukach torów, zwłaszcza pojazdów wózkowych.

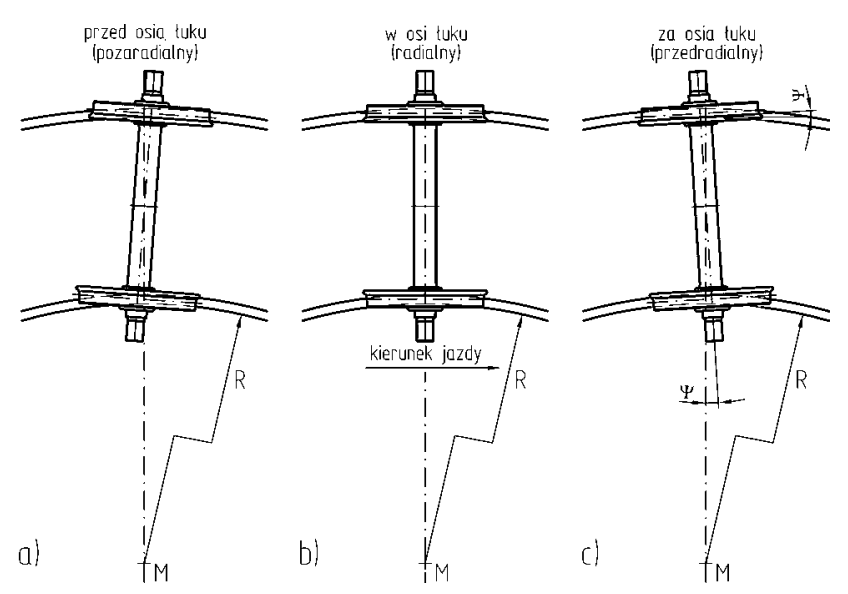

Rys.4. Ustawienia zestawu kołowego w torze

Specyfika eksploatacji pojazdów tramwajowych w porównaniu do pojazdów kolejowych polega na występowaniu małych łuków toru, o promieniu $\mathrm{R}=20 \div 25$ $\mathrm{m}$ oraz braku poszerzeń na łukach toru. Ewentualny luz zestawu kołowego w torze o określonym promieniu wynika $z$ :

- prześwitu toru S (na który składa się wymiar nominalny prześwitu, jego tolerancja oraz dopuszczalne zużycie boków szyn)

- zewnętrznego rozstawu obrzeży kół d ( ang. „flange gauge at the greatest possible wear”, niem. „, äußerer Abstand der Spurkränze, gemessen $10 \mathrm{~mm}$ unterhalb des Laufkreises ), który jest mierzony na powierzchni zarysu zewnętrznego wieńców kół w odległości wynoszącej $10 \mathrm{~mm}$ powyżej powierzchni tocznej kół.

\section{Analiza wielkości przemieszczeń na luku toru i na torze prostym dla tramwaju wg obowiązują- cych przepisów krajowych}

\subsection{Uwagi ogólne}

Obliczenia dopuszczalnego zarysu pojazdu tramwajowego wg PN-K-92008:1998 [10] oraz PN-K92008/Ap1 [11] przeprowadza się w oparciu o model przedstawiony na rys.5.

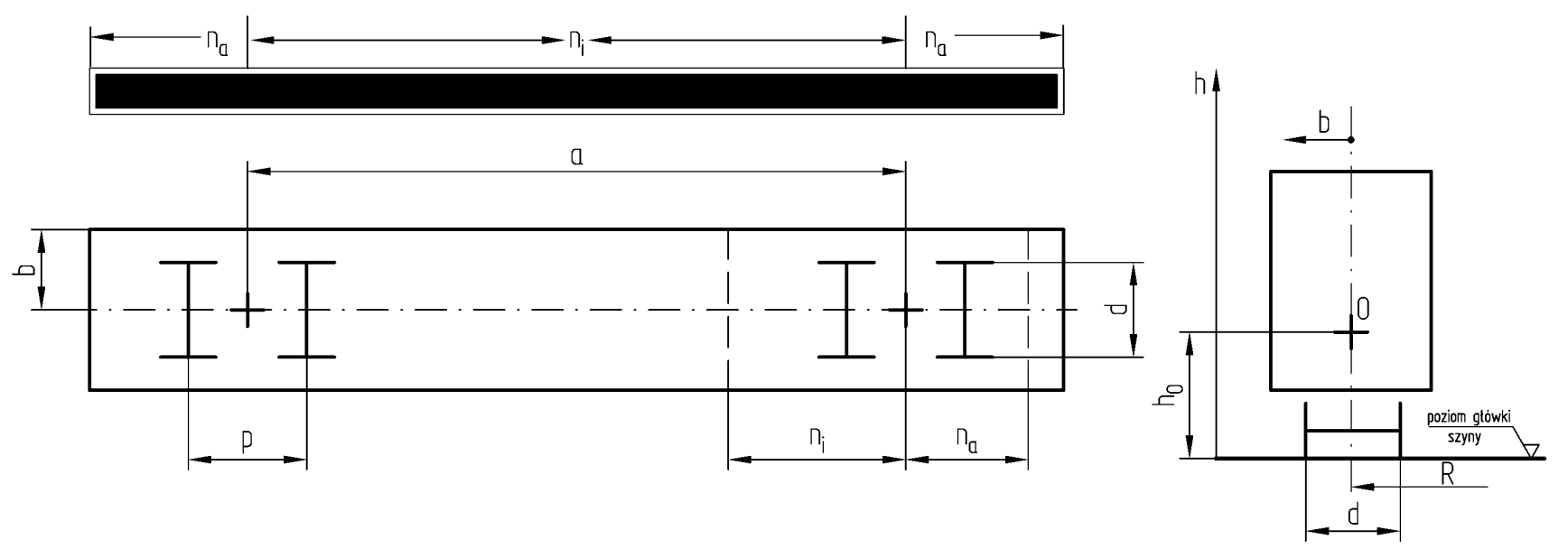

Rys.5. Model pojazdu tramwajowego przyjmowany do obliczeń dopuszczalnego zarysu pojazdu 
a- baza pojazdu tramwajowego ( odległość pomiędzy czopami skrętu lub umownymi środkami obrotu wózków) [m]

p- baza wózka [m]

$n_{i^{-}}$odlegtość rozpatrywanego przekroju pojazdu od umownego czopa skrętu $w$ kierunku wewnętrznym pojazdu (środka obrotu wózka) [m]

$n_{a^{-}}$odległość rozpatrywanego przekroju pojazdu od umownego czopa skrętu $w$ kierunku zewnętrznym pojazdu [m]

$h_{O^{-}}$wysokość bieguna przechylania względem główki szyny $[\mathrm{m}]$

h- wysokość rozpatrywanego punktu przekroju pojazdu szynowego $[\mathrm{m}]$

$d$ - rozstaw zewnętrzny obrzeży zestawu kołowego [m]

$R$ - promień tuku toru [m]

b- efektywna szerokość połowy pojazdu tramwajowego [m].

3.2. Wielkości zwężeń wewnętrznych oraz zewnętrznych na przykladzie wybranego pojazdu tramwajowego $105 \mathrm{~N}$

Przyjmując dane wymiarowe dla tramwaju:

- baza pojazdu a $=6 \mathrm{~m}$

- baza wózka p=1,9 m

- luz przymaźniczny w kierunku poprzecznym $\mathrm{q}=0,005 \mathrm{~m}$

- luz belki bujakowej względem ramy wózka w kierunku poprzecznym $\mathrm{w}=0,030 \mathrm{~m}$

- współczynnik pochylania $\mathrm{s}=0,300$

- asymetria liniowa $\mathrm{e}=0,007 \mathrm{~m}$

- asymetria kątowa $\theta=0^{\circ} 45^{\prime}$

- wysokość bieguna pochylania (kołysania pudła) od główki szyny $\mathrm{h}_{0}=0,460 \mathrm{~m}$

- dopuszczalne zużycie kół w kierunku promieniowym $z_{\mathrm{k}}=0,025 \mathrm{~m}$

- pionowe ugięcie statyczne sprężyn pudła wynikające $\mathrm{z}$ masy pasażerów $\mathrm{f}_{\text {stp }}=0,046 \mathrm{~m}$

- pionowe ugięcie dynamiczne sprężyn wózka od masy pasażerów $\mathrm{f}_{\mathrm{dwp}=}=0,003 \mathrm{~m}$

- pionowe ugięcie dynamiczne sprężyn pudła $\mathrm{f}_{\mathrm{dp}}=0,025 \mathrm{~m}$

- pionowe ugięcie dynamiczne sprężyn wózka $\mathrm{f}_{\mathrm{dw}}=0,001 \mathrm{~m}$

- odległość odbijaka resorowego od podłużnej płaszczyzny symetrii tramwaju $b_{\text {odb }}=0,641 \mathrm{~m} \mathrm{w}$ kierunku poprzecznym,

wykonano obliczenia zwężeń wewnętrznych oraz zewnętrznych dla wybranych punktów przekroju poprzecznego pojazdu tramwajowego dla łuku o promieniu $\mathrm{R}=20 \mathrm{~m}$ (najmniejszym dopuszczalnym określonym przez normę PN-K-92008 [10] ).
Wartości zwężeń wewnętrznych $\mathrm{E}_{\mathrm{i}}$ dla współrzędnych $\mathrm{n}_{1}=1 \mathrm{~m}, \mathrm{n}_{2}=1,5 \mathrm{~m}, \mathrm{n}_{3}=2 \mathrm{~m}, \mathrm{n}_{4}=2,5 \mathrm{~m} \mathrm{i}_{5}=3 \mathrm{~m}$ przedstawiono $\mathrm{w}$ tabeli 1 przy założeniu charakterystycznych punktów zarysu skrajni kinematycznej tzn. $\mathrm{W}=1,2 \mathrm{~m}$ i h=0,06 $\mathrm{m}, \mathrm{W}=1,350 \mathrm{~m}$ i $\mathrm{h}=3,2 \mathrm{~mm}$ oraz $\mathrm{W}=1,1 \mathrm{~m} \mathrm{i} \mathrm{h}=3,4 \mathrm{~m}$.

Zwężenia obliczono przy wykorzystaniu wzoru na zwężenia wewnętrzne wg normy PN-K-92008 [10]:

$$
\begin{aligned}
& E_{i}=\left|\left[1+\frac{(a-2 n)^{2}}{8 R^{2}}\right] \cdot \frac{\left|n(a-n)+\frac{p^{2}}{4}-10\right|}{2 R}-\frac{(a-2 n)^{2}}{8 R^{2}} \cdot W\right|+ \\
& +\frac{S-d}{2}+q+w+e+z
\end{aligned}
$$

gdzie:

W- współrzędna szerokości rozpatrywanego punktu przekroju pojazdu szynowego $[\mathrm{m}]$

S- prześwit toru $[\mathrm{m}]$

z- wyraz quasistatyczny [m]

Otrzymane wyniki zwężeń wewnętrznych nie zależą w tym przypadku od przemieszczeń geometrycznych, gdyż człon równania $n \cdot(a-n)+\frac{p^{2}}{4}-10$ dla a $=6 \mathrm{~m}$ i $p=1,9 \mathrm{~m}$ jest zawsze mniejszy od zera. Stąd wynika wniosek, że zwężenia wewnętrzne $\mathrm{E}_{\mathrm{i}}$ na łuku toru dla pojazdu tramwajowego są takie same jak na torze prostym.

Wartości zwężeń zewnętrznych $\mathrm{E}_{\mathrm{a}}$ dla współrzędnych $\mathrm{n}_{1}=0,25 \mathrm{~m}, \mathrm{n}_{2}=0,5 \mathrm{~m}, \mathrm{n}_{3}=0,75 \mathrm{~m}, \mathrm{n}_{4}=1$ $\mathrm{m}$ i $\mathrm{n}_{5}=1,5 \mathrm{~m}$ przedstawiono $\mathrm{w}$ tabeli 2 przy założeniu charakterystycznych punktów zarysu skrajni kinematycznej tzn. $\mathrm{W}=1,2 \mathrm{~m}$ i h=0,060 $\mathrm{m}, \mathrm{W}=1,350 \mathrm{~m}$ i $\mathrm{h}=3,2 \mathrm{~m}$ oraz $\mathrm{W}=1,1 \mathrm{~m}, \mathrm{~h}=3,4 \mathrm{~m}$.

Zwężenia obliczono przy wykorzystaniu wzoru na zwężenia zewnętrzne wg normy PN-K-92008 [10]:

(patrz strona 14)

W przypadku obliczeń zwężeń wewnętrznych oraz zewnętrznych należy uwzględnić przemieszczenie pionowe rozpatrywanego punktu przekroju poprzecznego pojazdu, które powstaje $\mathrm{w}$ wyniku ugięcia wszystkich stopni usprężynowania oraz zużyć elementów układu biegowego [10].

Zestawienie zwężeń wewnętrznych $\mathbf{E}_{\mathrm{i}}$ przykładowego pojazdu tramwajowego

\begin{tabular}{|c|c|c|c|c|c|c|c|c|}
\hline \multirow[t]{2}{*}{ L.p. } & \multirow[t]{2}{*}{$\mathrm{h}[\mathrm{m}]$} & \multirow[t]{2}{*}{$\mathrm{z}[\mathrm{m}]$} & \multirow{2}{*}{$\begin{array}{c}\mathrm{W} \\
{[\mathrm{m}]}\end{array}$} & \multicolumn{5}{|c|}{ Zwężenia wewnętrzne $\mathrm{E}_{\mathrm{i}}[\mathrm{m}]$} \\
\hline & & & & $\mathrm{n}_{1}=1 \mathrm{~m}$ & $\mathrm{n}_{2}=1,5 \mathrm{~m}$ & $\mathrm{n}_{3}=2 \mathrm{~m}$ & $\mathrm{n}_{4}=2,5 \mathrm{~m}$ & $\mathrm{n}_{5}=3 \mathrm{~m}$ \\
\hline 1. & 0,060 & 0,013 & 1,200 & \multicolumn{5}{|c|}{0,075} \\
\hline 2. & 3,200 & 0,091 & 1,350 & \multicolumn{5}{|c|}{0,153} \\
\hline 3. & 3,400 & 0,097 & 1,100 & \multicolumn{5}{|c|}{0,159} \\
\hline
\end{tabular}

Tabela 1 


$$
\begin{aligned}
E_{a} & =\left|\left[1+\frac{(a+2 n)^{2}}{8 R^{2}}\right]\left\{\frac{\left|n \cdot(a+n)-\frac{p^{2}}{4}-10\right|}{2\left(R+|25-R|_{>0}\right)}+\frac{|25-R|_{>0}\left|n \cdot(a+n)-\frac{p^{2}}{4}-10-\frac{8400}{R^{2}}\right|_{>0}}{50 R}\right\}-\frac{(a+2 n)^{2}}{8 R^{2}} \cdot W\right|_{>0}+ \\
& +\frac{2 n+a}{a} \cdot\left(\frac{S-d}{2}+q+w\right)+e+z
\end{aligned}
$$

Zestawienie zwężeń zewnętrznych $\mathbf{E}_{\mathrm{a}}$ przykładowego pojazdu tramwajowego

\begin{tabular}{|c|c|c|c|c|c|c|c|c|}
\hline \multirow[t]{2}{*}{ L.p. } & \multirow[t]{2}{*}{$\mathrm{h}[\mathrm{m}]$} & \multirow[t]{2}{*}{$\mathrm{z}[\mathrm{m}]$} & \multirow{2}{*}{$\begin{array}{c}\mathrm{W} \\
{[\mathrm{m}]}\end{array}$} & \multicolumn{5}{|c|}{ Zwężenia zewnętrzne $\mathrm{E}_{\mathrm{a}}[\mathrm{m}]$} \\
\hline & & & & $\mathrm{n}_{1}=0,25 \mathrm{~m}$ & $\mathrm{n}_{2}=0,5 \mathrm{~m}$ & $\mathrm{n}_{3}=0,75 \mathrm{~m}$ & $\mathrm{n}_{4}=1 \mathrm{~m}$ & $\mathrm{n}_{5}=1,5 \mathrm{~m}$ \\
\hline$\overline{1 .}$ & 0,060 & $\overline{0,013}$ & $\overline{1,200}$ & 0,079 & 0,084 & 0,088 & 0,093 & 0,102 \\
\hline 2. & 3,200 & 0,091 & 1,350 & 0,157 & 0,162 & 0,166 & 0,171 & 0,180 \\
\hline 3. & 3,400 & 0,097 & 1,100 & 0,163 & 0,168 & 0,172 & 0,177 & 0,186 \\
\hline
\end{tabular}

Tabela 2

\subsection{Analiza wybranych czynników mających decy- dujący wpływ na zwężenia wewnętrzne i ze- wnętrzne wózkowych pojazdów tramwajo- wych}

Analizie poddano następujące wybrane czynniki:

-wyraz quasistatyczny ,z"

-wysokość bieguna pochylania $h_{0}$

-współczynnik pochylania $\mathrm{s}$

-współczynnik wychylenia A

-luz zestawu kołowego w torze.

- Jak wynika $\mathrm{z}$ tabel 1 oraz 2 bardzo poważny udział w zwężeniach wewnętrznych $E_{\mathrm{i}}$ oraz zewnętrznych $\mathrm{E}_{\mathrm{a}}$ posiada wyraz quasistatyczny „z”, wyznaczany wg wzoru:

$$
z=\left(\frac{s}{15}+\operatorname{tg} \theta\right) \cdot\left(h-h_{0}\right)
$$

gdzie:

s- współczynnik pochylania [-]

$\theta$ - kąt asymetrii pojazdu tramwajowego $\left.{ }^{\circ}\right]$

h- wysokość punktu rozpatrywanego przekroju od główki szyny [m]

$\mathrm{h}_{0^{-}}$wysokość bieguna pochylania od główki szyny [m].

Wartość wyrazu ,z” rośnie wraz ze wzrostem wysokości h rozpatrywanego punktu przekroju poprzecznego oraz wartości współczynnika pochylania pojazdu s (niem. „Neigungskoeffizient”, ang. „,coefficient of flexibility"), co ma szczególne znaczenie w górnych partiach pojazdu. Przykładowa krzywa dla kąta asymetrii pojazdu tramwajowego $\theta=1^{\circ} 30^{\prime}$ oraz dla współczynnika pochylania $\mathrm{s}=0,4$ jest przedstawiona na rys.6. Zgodnie z PN-K-92008:1998 [10] ww. parametry przyjmują wartości dopuszczalne, określające zakres ważności normy.

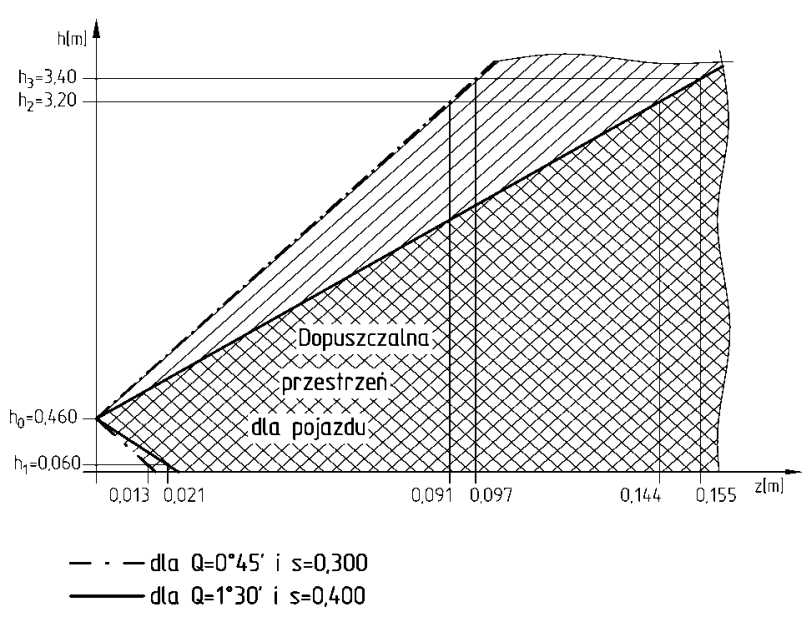

Rys.6. Udział przemieszczeń quasistatycznych „,z” w zwężeniach wewnętrznych $\mathrm{E}_{\mathrm{i}}$ oraz zewnętrznych $\mathrm{E}_{\mathrm{a}} \mathrm{w}$ pojeździe tramwajowym dla $\mathrm{h}_{0}=0,460 \mathrm{~m}$ oraz dla dwóch wartości współczynnika pochylania s

Wielkość zwężeń quasistatycznych „z” dla pojazdów tramwajowych z różnymi współczynnikami pochylania s oraz różnymi kątami asymetrii $\theta$ obliczono wg wzoru (3) i przedstawiono w tabeli 3.

Jak wynika z rys. 6 oraz tabeli 3 udział zwężeń quasistatycznych $\mathrm{z}=\mathrm{f}\left(\theta, \mathrm{s}, \mathrm{h}, \mathrm{h}_{0}\right)$ przyjmuje bardzo duże wartości, zwłaszcza $w$ górnych partiach wagonu tramwajowego, w związku z czym konieczne jest dokładne ustalenie wartości asymetrii kątowej $\theta$ oraz współczynnika pochylania s na drodze analitycznej oraz na drodze eksperymentalnej [3].

- Biegun pochylania (lub biegun kołysania, niem. „Wankpol”, ang. „roll centre”) określa się w PN-K92008 [10] jako „punkt wokół którego odbywa się kołysanie poprzeczne pudła wagonu tramwajowego", albo jako „punkt, którego przemieszczenie poprzeczne przyjmuje wartość zerową, jeśli do środka masy zostanie przyłożona siła poprzeczna $\mathrm{F}_{\mathrm{y}}$ o dowolnej wartości” [1]. 
Zestawienie zwężeń quasistatycznych „z” w zależności od współczynnika pochylania s oraz kąta asymetrii pojazdu $\theta$

Tabela 3

\begin{tabular}{|c|c|c|c|c|c|c|c|c|c|}
\hline \multirow[t]{2}{*}{ L.p. } & \multirow{2}{*}{$\begin{array}{c}\mathrm{h} \\
{[\mathrm{m}]}\end{array}$} & \multirow[b]{2}{*}{$\Theta\left[{ }^{\circ}\right]$} & \multicolumn{7}{|c|}{ Zwężenia quasistatyczne $\mathrm{z}$ [m] dla różnych wartości współczynników pochylania s } \\
\hline & & & $\mathrm{s}=0,1$ & $\mathrm{~s}=0,15$ & $\mathrm{~s}=0,2$ & $\mathrm{~s}=0,25$ & $\mathrm{~s}=0,3$ & $\mathrm{~s}=0,35$ & $\mathrm{~s}=0,4$ \\
\hline 1. & 0,06 & \multirow{3}{*}{$0,45^{\circ}$} & 0,007 & 0,009 & 0,010 & 0,011 & 0,013 & 0,0145 & 0,016 \\
\hline 2. & 3,20 & & 0,054 & 0,063 & 0,072 & 0,081 & 0,090 & 0,099 & 0,108 \\
\hline 3. & 3,40 & & 0,058 & 0,067 & 0,077 & 0,087 & 0,097 & 0,107 & 0,116 \\
\hline 4. & 0,06 & \multirow{3}{*}{$1^{\circ}$} & 0,009 & 0,010 & 0,020 & 0,013 & 0,015 & 0,016 & 0,017 \\
\hline 5. & 3,20 & & 0,066 & 0,075 & 0,084 & 0,093 & 0,102 & 0,111 & 0,120 \\
\hline 6. & 3,40 & & 0,070 & 0,080 & 0,090 & 0,100 & 0,110 & 0,119 & 0,129 \\
\hline 7. & 0,06 & \multirow{3}{*}{$1^{\circ} 30^{\prime}$} & 0,013 & 0,014 & 0,015 & 0,017 & 0,018 & 0,019 & 0,021 \\
\hline 8. & 3,20 & & 0,090 & 0,099 & 0,108 & 0,117 & 0,126 & 0,135 & 0,144 \\
\hline 9. & 3,40 & & 0,096 & 0,106 & 0,116 & 0,125 & 0,135 & 0,145 & 0,155 \\
\hline
\end{tabular}

Współczynnik pochylania s definiuje się ogólnie jako ( rys.7):

$$
s=\frac{\eta}{\delta}
$$

gdzie:

$\eta$ - odchylenie osi pionowej pudła od normalnej do płaszczyzny wyznaczonej przez główki szyn

$\delta$ - kąt odpowiadający przechyłce lub niedostateczności przechyłki toru.

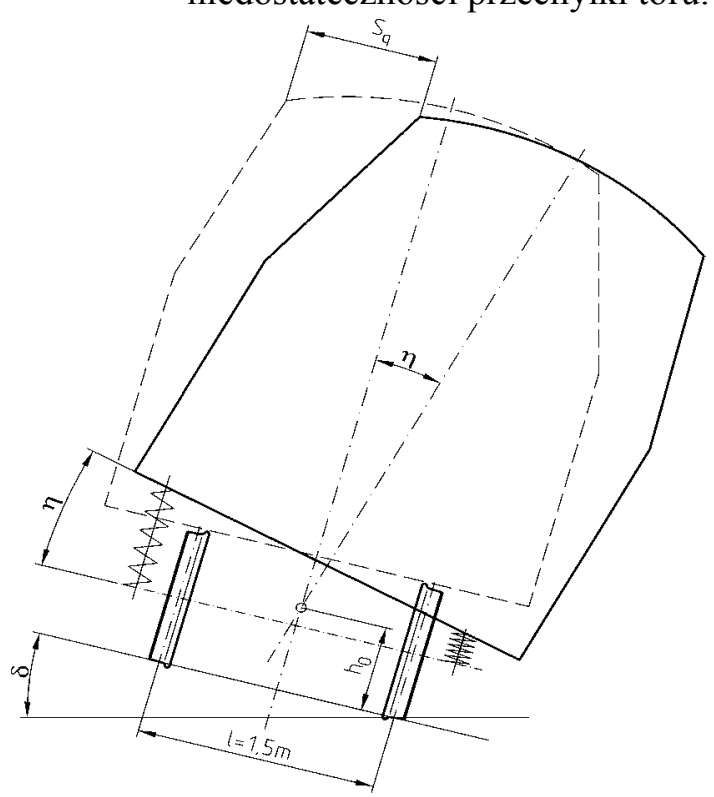

Rys.7. Pochylenie pudła pojazdu z jednostopniowym usprężynowaniem na łuku pod wpływem nadmiaru lub niedostateczności przechyłki toru

Ponieważ wózek tramwajowy posiada wielostopniowe usprężynowanie, współczynnik pochylania można wyznaczyć ze wzoru wyprowadzonego w [1]:

$$
s=\frac{Q_{r}^{\prime \prime} \cdot\left(h_{c}-h_{0}\right)}{c_{n k}-Q_{r}^{\prime \prime} \cdot\left(h_{c}-h_{0}\right)}
$$

gdzie:

$Q_{r}^{\prime \prime}$-siła ciężkości pochodząca od masy usprężynowanej

$\mathrm{h}_{\mathrm{c}}-\quad$ wysokość środka masy usprężynowanej części pojazdu $\mathrm{c}_{\mathrm{nk}}{ }^{-} \quad$ sztywność na kołysanie pojazdu $\mathrm{z}$ wielostopniowym usprężynowaniem.

Sztywność na kołysanie z dwustopniowym usprężynowaniem , $c_{2 \mathrm{k}}$ ” wyznacza się wg wzoru [1]:

$$
c_{2 k}=\frac{k_{1}^{2} \cdot l_{1}^{2} \cdot k_{2}^{2} \cdot l_{2}^{2}}{4\left(k_{1}^{2} \cdot l_{1}^{2}+k_{2}^{2} \cdot l_{2}^{2}\right)}
$$

gdzie:

$\mathrm{k}_{1}$-sztywność usprężynowania pierwszego stopnia

$\mathrm{k}_{2}$-sztywność usprężynowania drugiego stopnia

11-odległość pomiędzy osiami sprężyn lewej i prawej strony usprężynowania pierwszego stopnia

12-odległość pomiędzy osiami sprężyn lewej i prawej strony usprężynowania drugiego stopnia.

Zgodnie $\mathrm{z}$ przyjętymi zasadami obliczania skrajni $\mathrm{w}$ kolejnictwie, współczynnik pochylania należy zbadać $\mathrm{w}$ stanie próżnym i w stanie ładownym jak również w stanach pośrednich (jeśli występuje taka potrzeba) oraz przyjąć do obliczeń zwężeń największą wartość tego współczynnika [1]. Zaleca się, aby w takich przypadkach wykonywać badania współczynnika pochylania na drodze eksperymentalnej oraz wykonać porównanie $\mathrm{z}$ wartościami otrzymanymi na drodze analitycznej, analogicznie jak w przypadku pojazdów kolejowych [1 i 8]. W przypadku wystąienia znaczących niezgodności należy dokonać analizy poprawności zastosowanej metody pomiarowej oraz metody obliczeniowej i wykonać odpowiednie przedsięwzięcia korygujące. Czynnikiem zakłócającym pomiar współczynnika pochylania jest histereza tarcia występująca $\mathrm{w}$ różnych stopniach usprężynowania, w związku $\mathrm{z}$ czym zaleca się wykonywanie pomiarów przy wyłączonych thumikach drgań.

-Współczynnik wychylenia lub zwężenia A (ang. „displacement factor”, niem. „Einschränkungsfaktor”) przyjęto we wzorze (2) jako wynoszący $A=\frac{2 n+a}{a}$. 
Jednak, w miarę postępu prac studialnych, bardziej zbliżona do rzeczywistości jest sytuacja przedstawiona na rys. 8, uznana $\mathrm{w}$ kolejnictwie jako miarodajna dla wagonów osobowych oraz wagonów towarowych.

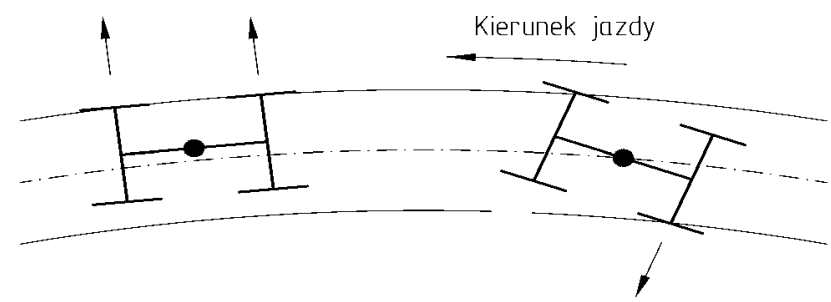

Rys.8 . Ustawienie narożnikowe pojazdu tramwajowego w torze wg [1]
Początkowo na etapie tworzenia przepisów kolejowych, czyli tzw. skrajni Jedności Technicznej, przyjęto największą wartość współczynnika wychylenia, uznając przypadek położenia narożnikowego wg rys.2 jako najbardziej miarodajny. Jako przykład może tutaj posłużyć jeszcze obowiązujący dokument wyznaczania dopuszczalnego zarysu pojazdu w oparciu o PN70/K-02056 [9].

Pierwszy komentarz o możliwości przyjęcia mniejszego współczynnika wychylenia A pojawił się w karcie UIC 505-5 [8]. Jeśli uwzględni się sytuację położenia skrajnie narożnikowego na łuku przedstawioną na rys.8 wówczas wzór (2) na zwężenia zewnętrzne pojazdu tramwajowego przyjmuje postać:

$E_{a}=\left\lfloor\left[1+\frac{(a+2 n)^{2}}{8 R^{2}}\right]\left\{\frac{\left|n \cdot(a+n)-\frac{p^{2}}{4}-10\right|_{>0}}{2\left(R+|25-R|_{>0}\right)}+\frac{|25-R|_{>0}\left|n \cdot(a+n)-\frac{p^{2}}{4}-10-\frac{8400}{R^{2}}\right|_{>0}}{50 R}\right\}-\left.\frac{(a+2 n)^{2}}{8 R^{2}} \cdot W\right|_{>0}+\cdot\right.$

$+\frac{n+a}{a} \cdot S+\frac{2 n+a}{a} \cdot(q+w)+e+z$

Wówczas wyniki zwężeń zewnętrznych $\mathrm{E}_{\mathrm{a}}$ przyjmą wartości przedstawione w tabeli 4.

Wartości zwężeń zewnętrznych $\mathrm{E}_{\mathrm{a}}$ obliczone wg wzoru (7)

Tabela 4

\begin{tabular}{|l|l|l|l|l|c|c|c|c|}
\hline L.p. & $\mathrm{h}[\mathrm{m}]$ & $\mathrm{z}[\mathrm{m}]$ & $\mathrm{W}$ & \multicolumn{5}{|c|}{ Zwężenia zewnętrzne $\mathrm{E}_{\mathrm{a}}[\mathrm{m}]$} \\
\cline { 5 - 9 } & & & {$[\mathrm{m}]$} & $\mathrm{n}_{1}=0,25 \mathrm{~m}$ & $\mathrm{n}_{2}=0,5 \mathrm{~m}$ & $\mathrm{n}_{3}=0,75 \mathrm{~m}$ & $\mathrm{n}_{4}=1 \mathrm{~m}$ & $\mathrm{n}_{5}=1,5 \mathrm{~m}$ \\
\hline 1. & 0,060 & 0,013 & 1,200 & 0,078 & 0,082 & 0,086 & 0,089 & 0,097 \\
\hline 2. & 3,200 & 0,091 & 1,350 & 0,156 & 0,160 & 0,164 & 0,167 & 0,175 \\
\hline 3. & 3,400 & 0,097 & 1,100 & 0,162 & 0,166 & 0,170 & 0,173 & 0,181 \\
\hline
\end{tabular}

$\mathrm{Z}$ porównania wyników zwężeń zewnętrznych $\mathrm{E}_{\mathrm{a}}$ przedstawionych $\mathrm{w}$ tabeli 2 i tabeli 4 wynika, że przy zastosowaniu wzoru (7) zwężenia zewnętrzne $\mathrm{E}_{\mathrm{a}}$ są o kilka milimetrów mniejsze, co wpływa korzystnie na kształt pojazdu. W karcie UIC 505-1 [7] przedstawiono studium wartości współczynnika wychylenia A w zależności od usytuowania pojazdu kolejowego w torze. Pomimo, że wyniki prac studialnych dotyczą pojazdów kolejowych, pojazdy tramwajowe przez analogię podlegają bardzo podobnym regułom. Wyniki prac studialnych przeprowadzonych dla współczynnika wychylenia A dla pojazdów kolejowych na podstawie karty UIC 505-1 [7] są przedstawione w tabeli 5 oraz 6. 
Wartości współczynnika wychylenia A dla różnych ustawień położenia pojazdu w torze prostym oraz dla luku toru dla pojazdów kolejowych, które stosuje się we wzorach na zwężenia wewnętrzne $\mathbf{E}_{\mathrm{i}}$ wg karty UIC 505-1 [7]

Tabela 5

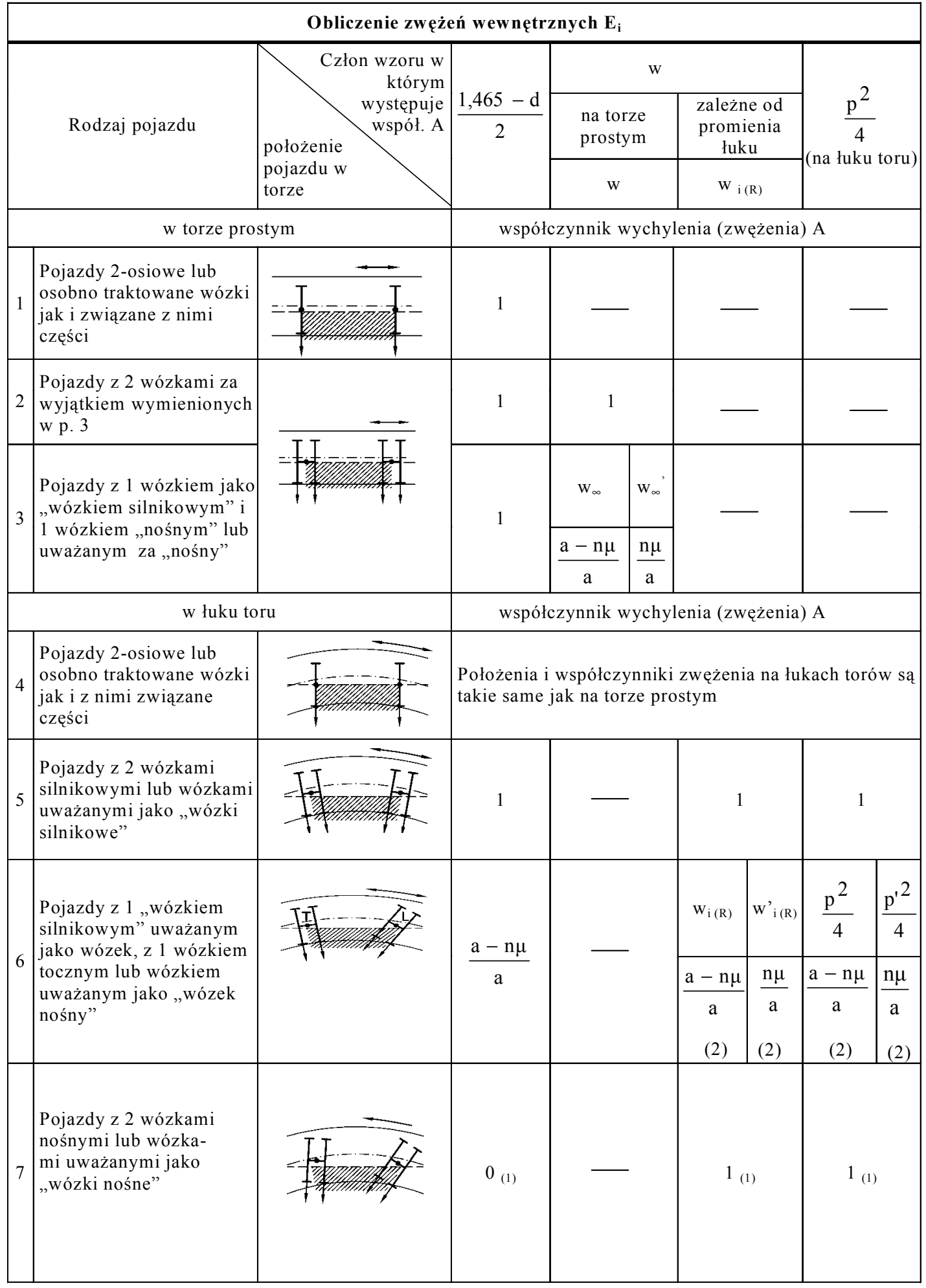

(1) przypadek szczególny dla wagonów towarowych

(2) współczynnik przyczepności o wartościach:

- $\mu \geq 0,2$ dla wózka trakcyjnego

- $0 \leq \mu<0,2$ dla wózka tocznego

$w_{i(R)}$ - luz poprzeczny pomiędzy belkq bujakowq oraz ramq zależny od promienia $R$ tuku toru $w$ kierunku wewnętrznym tuku $w_{\infty}$-luz poprzeczny na torze prostym

$\mathrm{W}_{\mathrm{i}(\mathrm{R})}^{\prime}, \mathrm{W}_{\infty}^{\prime}-j . w$. dla zespołów trakcyjnych wieloczłonowych $z$ wózkami napędnymi

p'- baza wózka napędnego zespolu trakcyjnego wieloczłonowego. 
Wartości współczynnika wychylenia A dla różnych ustawień położenia pojazdu w torze prostym oraz dla łuku toru dla pojazdów kolejowych, które stosuje się we wzorach na zwężenia zewnętrzne $\mathbf{E}_{\mathrm{a}}$ wg karty UIC 505-1 [7]

Tabela 6

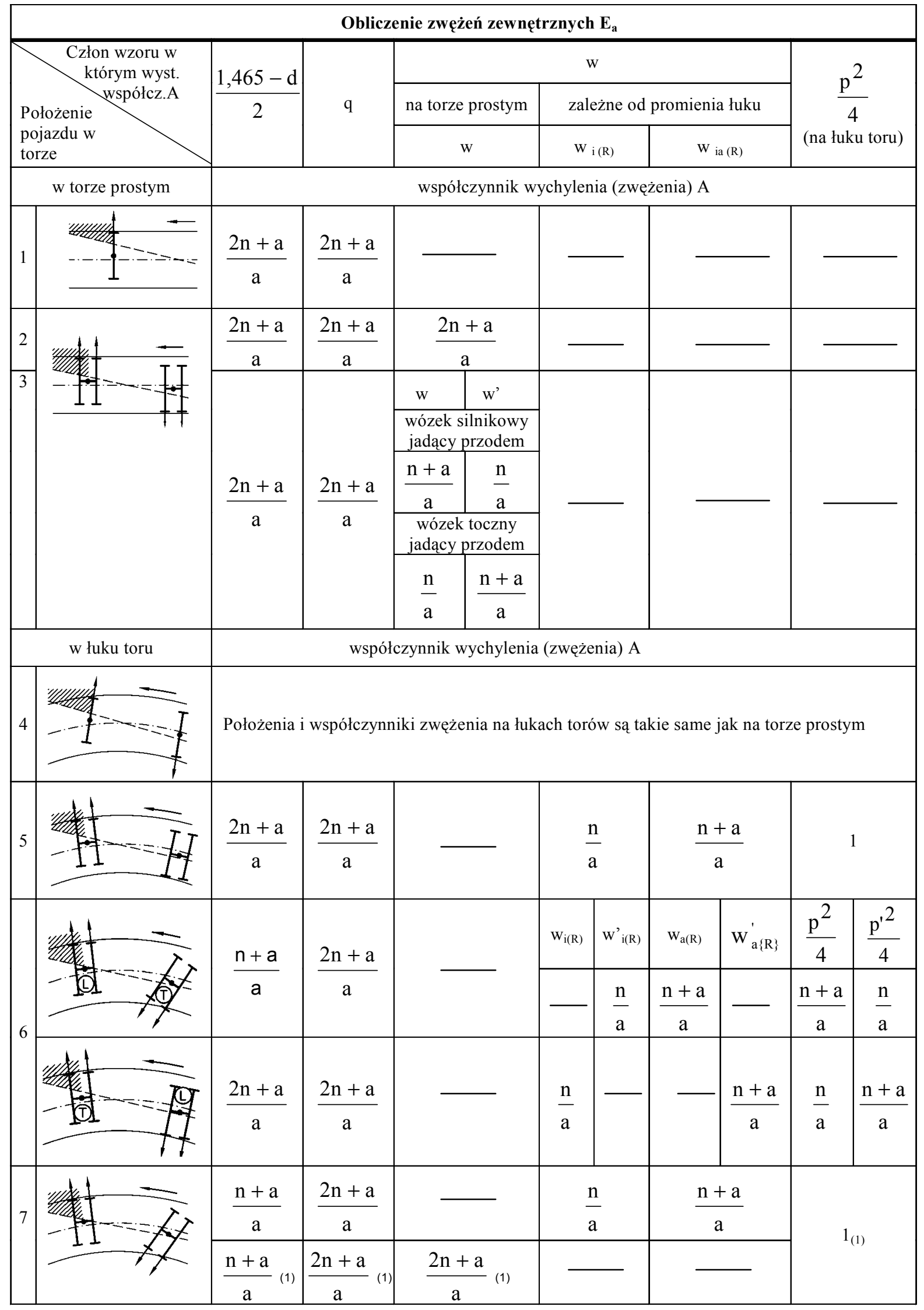

gdzie:

$w_{a(R)}$ - luz poprzeczny pomiędzy belkq bujakowq oraz ramq zależny od promienia $R$ tuku toru w kierunku zewnętrznym tuku $\mathrm{W}_{\mathrm{a}}^{\prime}$-j.w. dla zespolów trakcyjnych wieloczlonowych z wózkami napędnymi; $L$ - wózek toczny; P- wózek napędny.

Pozostate oznaczenia jak dla tabeli 5. 
W związku z powyższym należy wziąć pod uwagę, że przyjęcie współczynnika wychylenia na poziomie $A=\frac{2 n+a}{a}$ we wzorach na zwężenia (1) i (2) nie jest błędem z punktu widzenia bezpieczeństwa eksploatacyjnego, zdefiniowanego jako zabezpieczenie przed złożeniem się wszystkich niekorzystnych przypadków (ang. „worst case”). Przyjęcie jednak bardziej realnych wartości współczynników wychylenia A, odzwierciedlających rzeczywiste przypadki eksploatacyjne we wzorach na zwężenia zbliża do odtworzenia rzeczywistych wartości przemieszczeń na torze prostym oraz na łukach toru, co pozwala na osiagnięcie bardziej optymalnej konstrukcji z punktu widzenia własności użytkowych pojazdu. Dla każdego przypadku pojazdu tramwajowego należy rozważyć rzeczywiste wartości współczynnika wychylenia A we wzorach na zwężenia wewnętrzne oraz zewnętrzne, co może prowadzić do zwiększonego, rzeczywistego zarysu pojazdu jak wykazała analiza wg wzoru (7).

- Maksymalny luz zestawu kołowego w torze występuje wtedy, gdy wymiar „d” przyjmuje wartość minimalną wynoszącą $\mathrm{d}=1410 \mathrm{~mm}$ a prześwit toru przy skrajnie zużytych szynach wartość maksymalną $\mathrm{S}=1455 \mathrm{~mm}$. Przyjmując wzory na zwężenia wewnętrzne oraz zewnętrzne założono, że wszystkie zestawy kołowe czteroosiowego pojazdu tramwajowego zużywają się równomiernie i osiagają wymiar graniczny d. Osiagnięcie wymiaru granicznego jest tym szybsze, im bardziej zwiększają się kąty nabiegania $\psi$ zestawu kołowego na szyny ( rys.4c) i powolniejsze w przypadku radialnego ustawiania się zestawu kołowego w torze (rys.4b). Ostatnio jednak coraz bardziej zyskuje na znaczeniu ograniczenie wymiaru „d”, chociażby z tego względu, że toczenie skrajnie zużytych zestawów kołowych jest nieekonomiczne ( reprofilacja powoduje konieczność zebrania znacznych warstw materiału). Wydaje się więc, że wprowadzenie toczenia ekonomicznego przy ograniczeniu wymiaru "d" do wartości $\mathrm{d}=1415 \mathrm{~mm}$ lub $\mathrm{d}=1418 \mathrm{~mm}$ jest uzasadnione. Powoduje to tym samym zwiększenie szerokości dopuszczalnego zarysu pojazdu tramwajowego $\mathrm{w}$ pierwszym przypadku przynajmniej o $5 \mathrm{~mm}$, natomiast w drugim przypadku aż o $8 \mathrm{~mm}$ ( wzór (1)).

\subsection{Możliwości korekty obowiązujących wzorów na zwężenia zewnętrzne oraz wewnętrzne w oparciu o prace studialne dla pojazdów kole- jowych}

W oparciu o p.3.3. i prace studialne dla pojazdów kolejowych istnieją następujące możliwości korekty poszczególnych czynników w obowiązujących wzorach na obliczenia zwężeń dla pojazdów tramwajowych:

> wyrazu korekcyjnego ,z” poprzez dokładne określenie parametrów kąta asymetrii pojazdu „, $\theta$ ”, współczynnika pochylania „s” i bieguna pochylania , $\mathrm{h}_{0}$,
> wysokości bieguna pochylania $\mathrm{h}_{0}$ poprzez wyznaczanie na drodze analitycznej i eksperymentalnej, zamiast przyjmowania wartości ryczałtowych

$>$ współczynnika pochylania „s” poprzez wyznaczenie na drodze analitycznej i eksperymentalnej; przyjmowanie wartości wyznaczonych dla innych konstrukcji pojazdów tramwajowych lub jakichkolwiek wartości ryczałtowych jest niedopuszczalne

> współczynnika wychylenia A poprzez dokładną analizę konstrukcji pojazdu oraz jego ustawienia $\mathrm{w}$ torze

$>$ przemieszczenia zestawu kołowego wynikającego z prześwitu toru „S” oraz szerokości prowadnej zestawu kołowego; jeśli istnieje możliwość toczenia ekonomicznego wówczas minimalny wymiar „d” można ograniczyć do wartości $\mathrm{d}_{\mathrm{EK}}=1415 \mathrm{~mm}$ lub $\mathrm{d}_{\mathrm{EK}}=1418 \mathrm{~mm}$; w związku z tym we wzorach na zwężenia (1) i (2) należałoby wprowadzić wartość „, $\mathrm{d}_{\mathrm{EK}}=1415$ lub $\mathrm{d}_{\mathrm{EK}}=1418 \mathrm{~mm}$, pod warunkiem że jest stosowanie toczenie ekonomiczne zarysów zewnętrznych wieńców kół tramwajowych.

W efekcie proponowanych korekt uzyska się większą przestrzeń dla pudła pojazdu tramwajowego bez pogorszenia bezpieczeństwa eksploatacji pojazdu.

\section{Analiza wielkości przemieszczeń na łuku toru dla pojazdów tramwajowych wg wytycznych niemieckich}

Przemieszczenia pojazdów tramwajowych wg niemieckich wytycznych BOStrab [14] rozpatruje się dla następujących przypadków eksploatacyjnych:

- pojazdów eksploatowanych na trasach jednotorowych (niem. ,eingleisige Strecke”)

- pojazdów eksploatowanych na trasach wielotorowych ( niem. „mehrgleisige Strecke”), przy czym tory sąsiadują ze sobą ( niem.,, benachbarten Gleise") oraz

- pojazdów eksploatowanych na trasach wielotorowych, przy czym tory nie sąsiadują ze sobą ( niem. „nicht benachbarten Gleise”).

W przypadku przemieszczeń dla pojazdów tramwajowych eksploatowanych na trasach jednotorowych należy uwzględnić:

- odległość wybranych punktów pojazdu ( punktów krytycznych) od osi toru ( tzw. wystawanie geometryczne włącznie z połową szerokości pojazdu)

- przesunięcie poprzeczne pojazdu spowodowane luzem w torze

- przesunięcia poprzeczne spowodowane czynnikami, działającymi w sposób nieprzypadkowy i w tym samym kierunku 
- przemieszczenia poprzeczne spowodowane czynnikami, działającymi w sposób przypadkowy i w tym samym kierunku.

Dla przemieszczeń pojazdów tramwajowych eksploatowanych na trasach wielotorowych $\mathrm{z}$ sąsiadującymi torami należy dodatkowo uwzględnić:

-wpływ wiatru działającego tylko na jeden pojazd

-przesunięcia poprzeczne obydwu torów wynikające z czynników przypadkowych.

Położenia pojazdu, które są uznane przez niemieckie wytyczne BOStrab [14] jako najbardziej niekorzystne, są przedstawione na rys. 9 i 10.

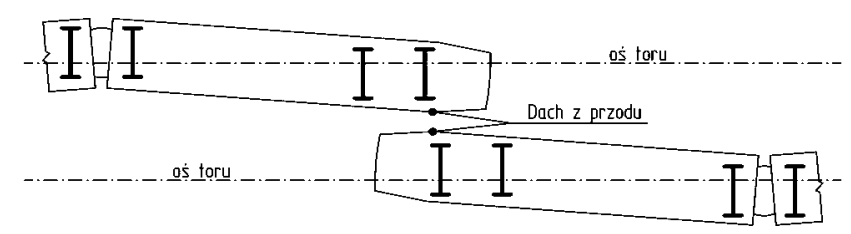

Rys.9. Położenie narożnikowe pojazdów tramwajowych na torze prostym

$\mathbf{a}$

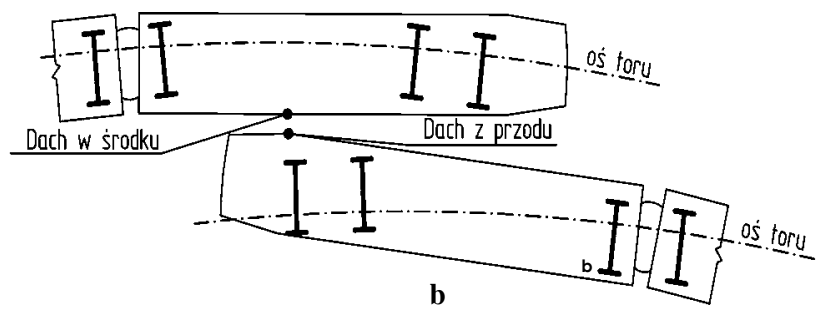

Rys.10. Położenie pojazdów tramwajowych na łuku, przy czym: a- jest w położeniu skrajnie wewnętrznym ( tor zewnętrzny),

b- znajduje się w położeniu narożnikowym ( tor wewnętrzny)

Autorzy wytycznych BOStrab[14] wyszli z założenia, że należy posłużyć się tylko jednym zarysem odniesienia tzn. zarysem odniesienia skrajni kinematycznej budowli (zarys odniesienia dla urządzeń stałych). Zrezygnowano więc przy wyznaczaniu dopuszczalnego zarysu pojazdu tramwajowego z korzystania z ,zarysu odniesienia skrajni kinematycznej pojazdu".Zaletą takiej metody jest przede wszystkim jej uniwersalność, a więc możliwość zastosowania dla różnych pojazdów o różnej budowie (np. pojazdy przegubowe), co bardziej odpowiada rzeczywistej sytuacji eksploatacyjnej wielu miast polskich i zagranicznych, gdzie kursuja tramwaje różnych typów [4]. Metoda wyznaczania dopuszczalnego zarysu pojazdu na podstawie obliczenia jego kinematycznego zapotrzebowania przestrzeni (niem. „Lichtraumbedarf”) zmusza jednak konstruktora pojazdu do gruntownego poznania przepisów infrastruktury [15]. Kinematyczne zapotrzebowanie przestrzeni dla danego pojazdu porównuje się z zarysem odniesienia skrajni budowli ( niem.,,Umgrenzung des Lichtraumbedarfes", ang.,,lineside structure installation gauge) lub wykorzystuje się do analizy, mającej na celu ustalenie bezkolizyjnego przejazdu pomiędzy mijającymi się pojazdami tramwajowymi. Jak wynika z paragrafu 18 ustęp 1 wytycznych BOStrab [14], pomiędzy kinematycznym zapotrzebowaniem przestrzeni oraz zarysem skrajni budowli powinien być przewidziany luz bezpieczeństwa (niem. „Sicherheitsabstand”). Z luzu bezpieczeństwa można zrezygnować pod warunkiem, że w kinematycznym zapotrzebowaniu przestrzeni uwzględni się wszystkie możliwe stany eksploatacyjne.

W związku z powyższym kinematyczne zapotrzebowanie przestrzeni wg wytycznych BOStrab [14] dla poszczególnych przypadków wyznacza się z ogólnego wzoru [4]:

$$
y=y_{n z 1}+y_{n z 2}+\ldots \ldots . . . y_{n z i}+\sqrt{y_{z 1}^{2}+y_{z 2}^{2}+\ldots . . y_{z j}^{2}}
$$

gdzie:

$-\mathrm{y}_{\mathrm{nz} 1}, \mathrm{y}_{\mathrm{nz2} 2}, \ldots \ldots . . . \mathrm{y}_{\mathrm{nzi}}{ }^{-}$przemieszczenia wywołane czynnikami nieprzypadkowymi

( niem. ,nicht zufallsbedingt”)

$-\mathrm{y}_{\mathrm{z} 1}, \mathrm{y}_{\mathrm{z} 2}, \mathrm{y}_{\mathrm{z} 3} \ldots \ldots . . \mathrm{y}_{\mathrm{z} j}-$ przemieszczenia wywołane czynnikami przypadkowymi (niem. ,zufallsbedingt”).

Wytyczne BOStrab [14] klasyfikują czynniki wpływające na przemieszczenia na dwie grupy:

- związane z pojazdem:

- tolerancji budowy pojazdu ( z)

- luzów ( nz)

- zużycia (nz)

- przemieszczeń poprzecznych usprężynowania $(n z, z)$

- związane $\mathrm{z}$ infrastrukturą:

- trwałe odkształcenia toru uwarunkowane eksploatacja, wynikające $\mathrm{z}$ tolerancji wykonawczych (nz, z)

- sprężyste odkształcenia toru wynikające $\mathrm{z}$ eksploatacji (nz).

$\mathrm{Na}$ zapotrzebowanie kinematyczne przestrzeni dla pojazdu znajdującego się na torze prostym oraz na łuku wg wzoru (8) składają się przemieszczenia przedstawione w tabeli 7.

W przypadku mijania się dwóch pojazdów tramwajowych znajdujących się na dwóch sąsiadujących torach prostych ( rys.9) kinematyczne zapotrzebowanie przestrzeni, będące bazą do odległości pomiędzy torami, wynosi wg wzoru (8) odpowiednio:

$$
\begin{aligned}
& y_{d}=2\left(b_{a}+y_{S S}+y_{S A}+y_{S D}+y_{F R}+y_{F P}+y_{F S}+y_{G E}+y_{W Q}+y_{W Z}+y_{H E}\right)+ \\
& +\sqrt{2\left(y_{S W}^{2}+y_{T R}^{2}+y_{T A}^{2}+\ldots\right.} \\
& \left.\sqrt{\left.\ldots+y_{T D}^{2}+y_{T P}^{2}+y_{T W}^{2}+y_{D S}^{2}\right)+y_{G W}^{2}+y_{G V}^{2}+y_{W W}^{2}+2\left(y_{W S}^{2}+y_{W B}^{2}+y_{H S}^{2}\right.}\right)
\end{aligned}
$$

Wielkość wystawania wybranego punktu $\mathrm{P}$ pojazdu $\mathrm{b}_{\mathrm{a}}$ w kierunku zewnętrznym łuku od osi toru lub $b_{i} w$ kierunku wewnętrznym łuku od osi toru można wyznaczyć na podstawie rys.11 
Przemieszczenia poprzeczne dla kinematycznego zapotrzebowania przestrzeni na torze prostym

Tabela 7

\begin{tabular}{|c|c|c|c|c|}
\hline L.p & $\begin{array}{l}\text { Oznaczenie wg wzoru } \\
\text { (8) }\end{array}$ & \multicolumn{2}{|c|}{ Oznaczenie } & $\begin{array}{l}\text { Definicja przemieszczenia poprzecznego } \\
\text { rozpatrywanego punktu P pojazdu tramwa- } \\
\text { jowego }\end{array}$ \\
\hline \multicolumn{5}{|c|}{ Czynniki nieprzypadkowe } \\
\hline \multirow[t]{2}{*}{1.} & & & $\overline{b_{a}}$ & $\begin{array}{l}\text { Odległość punktu P pojazdu od środka toru } \mathrm{w} \\
\text { wyniku geometrycznego wystawania w kierunku } \\
\text { zewnętrznym łuku toru włącznie z połową sze- } \\
\text { rokości pojazdu }\end{array}$ \\
\hline & $\mathrm{y}_{\mathrm{ynz} 1}$ & $\mathrm{~b}_{\mathrm{a}, \mathrm{i}}$ & $b_{i}$ & $\begin{array}{l}\text { Odległość punktu } \mathrm{P} \text { pojazdu od środka toru } \mathrm{w} \\
\text { wyniku geometrycznego wystawania w kierunku } \\
\text { wewnętrznym łuku toru włącznie z połową } \\
\text { szerokości pojazdu }\end{array}$ \\
\hline 2. & $\mathrm{y}_{\mathrm{nz2}}$ & \multicolumn{2}{|l|}{$\mathrm{y}_{\mathrm{SS}}$} & $\begin{array}{l}\text { Przesunięcie punktu pojazdu } \mathrm{z} \text { powodu luzu } \\
\text { zestawu kołowego w torze }\end{array}$ \\
\hline 3. & $\mathrm{y}_{\mathrm{nz} 3}$ & \multicolumn{2}{|c|}{$\mathrm{y}_{\mathrm{SA}}$} & $\begin{array}{l}\text { Przesunięcie poprzeczne spowodowane luzem } \\
\text { przymaźniczym }\end{array}$ \\
\hline 4. & $\mathrm{y}_{\mathrm{nz} 4}$ & \multicolumn{2}{|c|}{$\mathrm{y}_{\mathrm{SD}}$} & $\begin{array}{l}\text { Przesunięcie poprzeczne w wyniku luzu } \\
\text { rejonie czopa skrętu }\end{array}$ \\
\hline 5. & $\mathrm{y}_{\mathrm{nz} 5}$ & \multicolumn{2}{|l|}{$\mathrm{y}_{\mathrm{FR}}$} & $\begin{array}{l}\text { Przesunięcie poprzeczne usprężynowania koła } \\
\text { obręczowanego }\end{array}$ \\
\hline 6. & $\mathrm{y}_{\mathrm{nz} 6}$ & \multicolumn{2}{|l|}{$\mathrm{y}_{\mathrm{FP}}$} & $\begin{array}{l}\text { Przesunięcie poprzeczne usprężynowania pierw- } \\
\text { szego stopnia }\end{array}$ \\
\hline 7. & $\mathrm{y}_{\mathrm{nz} 7}$ & \multicolumn{2}{|l|}{$\mathrm{y}_{\mathrm{FS}}$} & $\begin{array}{l}\text { Przesunięcie poprzeczne usprężynowania dru- } \\
\text { giego stopnia }\end{array}$ \\
\hline 8. & $\mathrm{y}_{\mathrm{nz} 8}$ & \multicolumn{2}{|l|}{$\mathrm{y}_{\mathrm{GE}}$} & $\begin{array}{l}\text { Przesunięcie poprzeczne wynikające z elastycz- } \\
\text { ności toru i szyny }\end{array}$ \\
\hline 9. & $\mathrm{y}_{\mathrm{nz} 9}$ & \multicolumn{2}{|c|}{$\mathrm{y}_{\mathrm{WQ}}$} & $\begin{array}{l}\text { Przemieszczenia poprzeczne wynikające } \mathrm{z} \text { nad- } \\
\text { miaru lub nieskompensowanej siły odśrodkowej }\end{array}$ \\
\hline 10. & $\mathrm{y}_{\mathrm{nz} 10}$ & \multicolumn{2}{|c|}{$\mathrm{y}_{\mathrm{wZ}}$} & $\begin{array}{l}\text { Przesunięcie poprzeczne wynikające } \mathrm{z} \text { asymetrii } \\
\text { ladunku }\end{array}$ \\
\hline 11. & $\mathrm{y}_{\mathrm{nz} 11}$ & \multicolumn{2}{|l|}{$\mathrm{y}_{\mathrm{HE}}$} & $\begin{array}{l}\text { Przemieszczenie poprzeczne wynikające ze } \\
\text { wzajemnej różnicy wysokości szyn ( zakres } \\
\text { odkształceń sprężystych) }\end{array}$ \\
\hline \multicolumn{5}{|c|}{ Czynniki przypadkowe } \\
\hline 1. & $\mathrm{y}_{\mathrm{z} 1}$ & \multicolumn{2}{|l|}{$\mathrm{y}_{\mathrm{sw}}$} & $\begin{array}{l}\text { Przemieszczenie poprzeczne wynikające } \mathrm{z} \text { koły- } \\
\text { sania pudła w wyniku uderzenia bocznego spo- } \\
\text { wodowanego nierównością na torze; przyspie- } \\
\text { szenie uderzenia należy przyjmować na pozio- } \\
\text { mie } \mathrm{a}_{\mathrm{s}}= \pm 50 \mathrm{~m} / \mathrm{s}^{2}\end{array}$ \\
\hline 2. & $\mathrm{y}_{\mathrm{z} 2}$ & \multicolumn{2}{|l|}{$\mathrm{y}_{\mathrm{TR}}$} & $\begin{array}{l}\text { Przemieszczenia poprzeczne wynikające } \mathrm{z} \text { cech } \\
\text { budowy pojazdu: tolerancja konstrukcyjna ze- } \\
\text { stawu kołowego }\end{array}$ \\
\hline 3. & $\mathrm{y}_{\mathrm{z} 3}$ & \multicolumn{2}{|l|}{$\mathrm{y}_{\mathrm{TA}}$} & $\begin{array}{l}\text { Przemieszczenia poprzeczne wynikające } \mathrm{z} \text { cech } \\
\text { budowy pojazdu: tolerancja konstrukcyjna maź- } \\
\text { nicy }\end{array}$ \\
\hline 4. & $\mathrm{y}_{\mathrm{z} 4}$ & \multicolumn{2}{|l|}{$\mathrm{y}_{\mathrm{TD}}$} & $\begin{array}{l}\text { Przemieszczenia poprzeczne wynikające z cech } \\
\text { budowy pojazdu: tolerancja konstrukcyjna poła- } \\
\text { czenia czop skrętu-gniazdo skrętu }\end{array}$ \\
\hline 5. & $\mathrm{y}_{\mathrm{z} 5}$ & \multicolumn{2}{|l|}{$\mathrm{y}_{\mathrm{TP}}$} & $\begin{array}{l}\text { Przemieszczenia poprzeczne wynikające } \mathrm{z} \text { cech } \\
\text { budowy pojazdu: tolerancja konstrukcyjna } \\
\text { usprezżynowania pierwszego stopnia }\end{array}$ \\
\hline 6. & $\mathrm{y}_{\mathrm{z} 6}$ & \multicolumn{2}{|l|}{$\mathrm{y}_{\text {TW }}$} & $\begin{array}{l}\text { Przemieszczenia poprzeczne wynikające z cech } \\
\text { budowy pojazdu: tolerancja konstrukcyjna pudła } \\
\text { pojazdu }\end{array}$ \\
\hline 7. & $\mathrm{y}_{\mathrm{z} 7}$ & \multicolumn{2}{|l|}{$\mathrm{y}_{\mathrm{DS}}$} & $\begin{array}{l}\text { Przemieszczenia poprzeczne wynikające z ugię- } \\
\text { cia usprężynowania drugiego stopnia wskutek } \\
\text { obciążen dynamicznych }\end{array}$ \\
\hline 8. & $\mathrm{y}_{\mathrm{z} 8}$ & \multicolumn{2}{|l|}{$\mathrm{y}_{\mathrm{GW}}$} & $\begin{array}{l}\text { Przesunięcie poprzeczne wynikające ze zmiany } \\
\text { przesunięcia poprzecznego toru }\end{array}$ \\
\hline 9. & $\mathrm{y}_{\mathrm{z} 9}$ & \multicolumn{2}{|l|}{$\mathrm{y}_{\mathrm{GV}}$} & Przesunięcie poprzeczne toru \\
\hline 10. & $\mathrm{y}_{\mathrm{z} 10}$ & \multicolumn{2}{|l|}{$\mathrm{y}_{\mathrm{ww}}$} & $\begin{array}{l}\text { Przesunięcie poprzeczne wynikające z kołysania } \\
\text { pudła pojazdu spowodowanego wiatrem } \\
\text { ( przyjmuje się ciśnienie spowodowane wiatrem } \\
p_{\mathrm{w}}= \pm 200 \mathrm{~N} / \mathrm{m}^{2} \text { odpowiadające prędkości wiatru } \\
60 \mathrm{~km} / \mathrm{h} \text { ) }\end{array}$ \\
\hline
\end{tabular}


cd Tabeli 7

\begin{tabular}{|l|c|c|l|}
\hline 11. & $\mathrm{y}_{\mathrm{z} 11}$ & $\mathrm{y}_{\mathrm{WS}}$ & $\begin{array}{l}\text { Przesunięcie poprzeczne wynikające } \mathrm{z} \text { odchyłki } \\
\text { osi symetrii toru }\end{array}$ \\
\hline 12. & $\mathrm{y}_{\mathrm{z} 12}$ & $\mathrm{y}_{\mathrm{WB}}$ & $\begin{array}{l}\text { Przesunięcie poprzeczne wynikające z kąta } \\
\text { asymetrii pojazdu (regulacja) }\end{array}$ \\
\hline 13. & $\mathrm{y}_{\mathrm{z} 13}$ & $\mathrm{y}_{\mathrm{HS}}$ & $\begin{array}{l}\text { Przemieszczenie poprzeczne wynikające ze } \\
\text { wzajemnej różnicy wysokości szyn ( zakres } \\
\text { odkształceń trwałych) }\end{array}$ \\
\hline
\end{tabular}

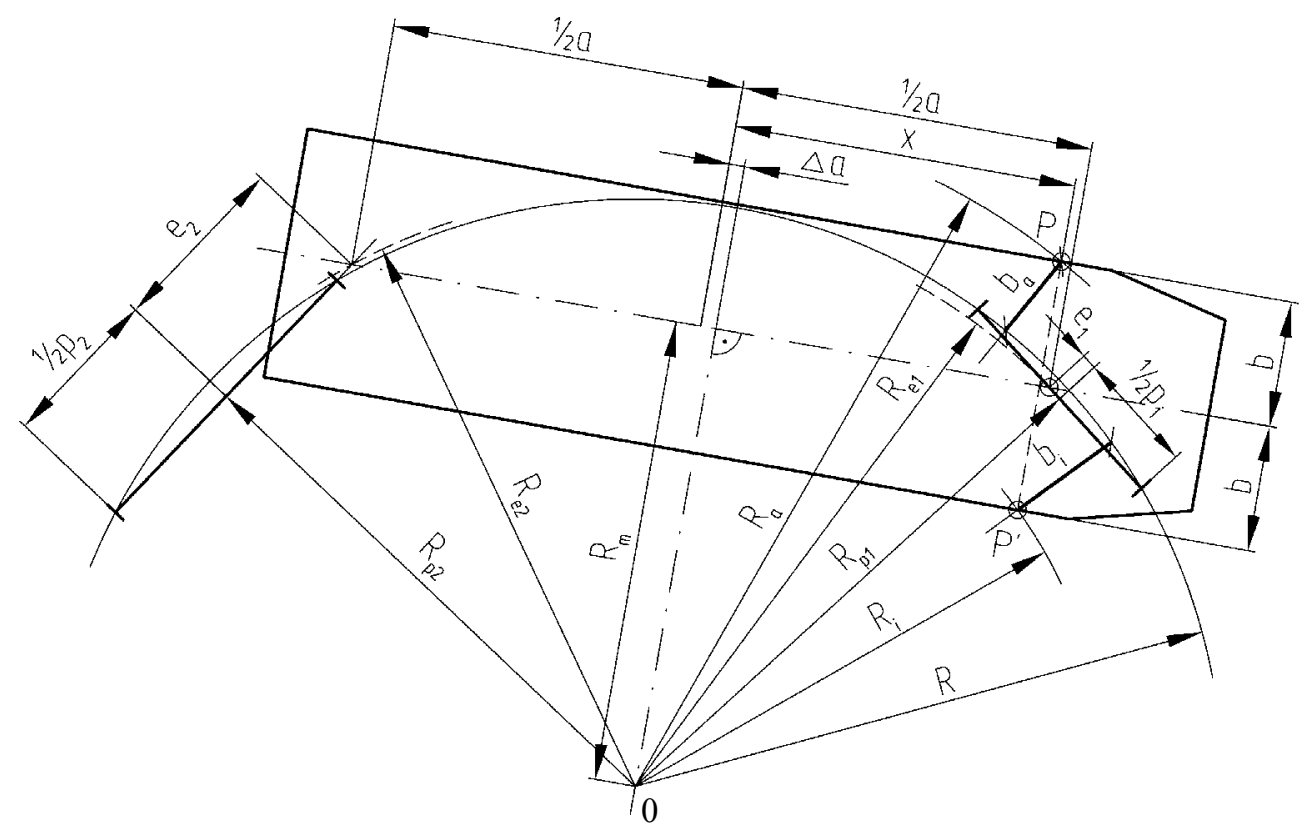

Rys.11. Wystawanie punktu P i P’ pojazdu tramwajowego o bazie „a” i z dwoma wózkami o różnych bazach $\mathrm{p}_{1}$ oraz $\mathrm{p}_{2}$ na łuku toru o promieniu $\mathrm{R}$

$\Delta a$ - odległość pomiędzy poprzecznq osia symetrii pojazdu i prosta prostopadta do osi wzdlużnej pojazdu przechodzqcej przez punkt „O” zaczepienia promienia $R$

b- $\quad$ szerokość połowy przekroju poprzecznego pojazdu tramwajowego

$b_{a^{-}} \quad$ odległość punktu P przekroju poprzecznego pojazdu od środka toru w wyniku wystawania w kierunku zewnętrznym tuku toru z uwzględnieniem połowy szerokości pojazdu

$b_{i^{-}}$odległość punktu P' przekroju poprzecznego pojazdu od środka toru $w$ wyniku wystawania $w$ kierunku wewnętrznym tuku toru z uwzględnieniem polowy szerokości pojazdu

$e_{1}, e_{2}$ - odległości pomiędzy środkami przegubów i środkami obrotu układów biegowych

$R_{a^{-}}$promień okręgu, na którym znajduje się rozpatrywany punkt P pojazdu

$R_{e l}, R_{e 2}$-promienie okręgów, na których znajduja się środki przegubów lub punkty oparcia pudła (niem. Anlenkpunkte)

$R_{p I}, R_{p 2}$-promienie okręgów, na których znajduja się punkty obrotu wózków lub środki symetrii układów biegowych

$R_{m^{-}} \quad$ odległość osi symetrii pojazdu od środka okregu wyznaczajacego luk toru

$R$ - $\quad$ promień tuku toru

x- $\quad$ wspótrzędna punktu $P$ i $P^{\prime}$

Wystawanie $b_{a} w$ kierunku zewnętrznym łuku od osi toru wynosi:

$$
b_{a}=\sqrt{\left(\sqrt{R^{2}-\frac{a^{2}}{4}-\frac{p_{1}^{2}+p_{2}^{2}}{8}+\frac{e_{1}^{2}+e_{2}^{2}}{2}-\left(\frac{p_{1}^{2}-p_{2}^{2}}{8 a}-\frac{e_{1}^{2}-e_{2}^{2}}{2 a}\right)^{2}}+b\right)^{2}+\left[x-\left(\frac{p_{1}^{2}-p_{2}^{2}}{8 a}-\frac{e_{1}^{2}-e_{2}^{2}}{2 a}\right)\right]^{2}}-R
$$

Wystawanie $b_{i} w$ kierunku wewnętrznym łuku od osi toru wynosi:

$$
b_{i}=R-\sqrt{\left(\sqrt{R^{2}-\frac{a^{2}}{4}-\frac{p_{1}^{2}+p_{2}^{2}}{8}+\frac{e_{1}^{2}+e_{2}^{2}}{2}-\left(\frac{p_{1}^{2}-p_{2}^{2}}{8 a}-\frac{e_{1}^{2}-e_{2}^{2}}{2 a}\right)^{2}}-b\right)^{2}+\left[x-\left(\frac{p_{1}^{2}-p_{2}^{2}}{8 a}-\frac{e_{1}^{2}-e_{2}^{2}}{2 a}\right)\right]^{2}}
$$


W przypadku gdy $\mathrm{p}_{1=} \mathrm{p}_{2}$ i $\mathrm{e}_{1}=\mathrm{e}_{2}=0$ wzór (10) i (11) przyjmuje postać:

$$
\begin{aligned}
& b_{a}=\sqrt{\left(R^{2}-\frac{a^{2}}{4}-\frac{p^{2}}{4}+b\right)^{2}+x^{2}}-R \\
& b_{i}=R-\sqrt{\left(R^{2}-\frac{a^{2}}{4}-\frac{p^{2}}{4}-b\right)^{2}+x^{2}}
\end{aligned}
$$

W przypadku mijania się dwóch pojazdów tramwajowych znajdujących się na dwóch sąsiadujących łukach toru ( rys.10) kinematyczne zapotrzebowanie przestrzeni, będące bazą do odległości pomiędzy torami, wynosi wg wzoru (8) odpowiednio:

$$
\begin{aligned}
& y_{d}=b_{a a}+b_{i b}+y_{S S b}+y_{S A b}+y_{S D a}+y_{S D b}+y_{F R a}+y_{F R b}+y_{F P a}+y_{F P b}+y_{F S a}+y_{F S b}+y_{W Z a}+ \\
& +y_{W Z b}+y_{H E a}+y_{H E b}+y_{G E a}+y_{G E b}+y_{W Q a}+y_{W Q b}+\sqrt{y_{S W a}^{2}+y_{S W b}^{2}+y_{T R a}^{2}+y_{T R b}^{2}+y_{T A a}^{2}+y_{T A b}^{2}+} \\
& \sqrt{+y_{T D a}^{2}+y_{T D b}^{2}+y_{T P a}^{2}+y_{T P b}^{2}+y_{D S a}^{2}+y_{D S b}^{2}+y_{T W a}^{2}+y_{T W b}^{2}+y_{W B a}^{2}+y_{W B b}^{2}+y_{H S a}^{2}+y_{H S b}^{2}+y_{W S a}^{2}+} \\
& \sqrt{y_{W S b}^{2}+y_{G W b}^{2}+y_{G V b}^{2}}
\end{aligned}
$$

gdzie indeksy użyte dla oznaczeń wymienionych w tabeli 7 dotyczą odpowiednio: indeks a-pojazdu tramwajowego znajdującego się na łuku wewnętrznym, natomiast indeks $b$-pojazdu tramwajowego znajdującego się na łuku zewnętrznym.

Jeśli wyznaczanie kinematycznego zapotrzebowania przestrzeni dotyczy pojazdu o nieznanych tolerancjach wykonania pojazdu i własnościach usprężynowania jak również nieznanych tolerancjach budowy i sprężystości toru, wówczas należy wykonać obliczenia $z$ pewnym zapasem i oprócz geometrycznego wystawania należy uwzględnić:

- maksymalny luz zestawu kołowego w torze

- maksymalne przesunięcie toru

- maksymalną odchyłkę wzajemnej wysokości szyn bez uwzględnienia wpływu przemieszczenia środka masy $\left(y_{H S}^{*}\right)$.

W takim przypadku dla pojazdu z przeciętnym komfortem jazdy i przy uwzględnieniu normalnego stanu utrzymania i konserwacji pojazdu i toru do ustalonego kinematycznego zapotrzebowania przestrzeni należy dodać luz bezpieczeństwa $y_{\mathrm{S}} \mathrm{w}$ zależności od wysokości badanego punktu pojazdu, o liniowym przebiegu, wynoszący przynajmniej $60 \mathrm{~mm} \mathrm{w}$ rejonie podłogi oraz $120 \mathrm{~mm}$ w rejonie dachu.

W związku z tym dla jednotorowej trasy kinematyczne zapotrzebowanie przestrzeni wynosi odpowiednio:

$$
y_{P}=b_{a, i}+y_{S S}+\sqrt{y_{G V}^{2}+y_{H S}^{* 2}}+y_{S}
$$

W przypadku mijania się dwóch pojazdów tramwajowych znajdujących się na dwóch sąsiadujących torach prostych ( rys.9) kinematyczne zapotrzebowanie przestrzeni, będące bazą do odległości pomiędzy torami wynosi odpowiednio:

$$
y_{d}=2\left(b_{a}+y_{S S}\right)+\sqrt{y_{G V}^{2}+2 y_{H S}^{* 2}}+2 y_{S}
$$

W przypadku mijania się dwóch pojazdów tramwajowych znajdujących się na dwóch sąsiadujących łukach toru ( rys.10) kinematyczne zapotrzebowanie przestrzeni, będące bazą do odległości pomiędzy torami wynosi odpowiednio:

$$
y_{d}=b_{a a}+b_{i b}+y_{S S b}+\sqrt{y_{G V b}^{2}+y_{H S a}^{* 2}+y_{H S b}^{* 2}}+2 y_{s}
$$

Przedstawiona metodyka wyznaczania kinematycznego zapotrzebowania przestrzeni jest zbliżona do nowoczesnego podejścia dla pojazdów kolejowych przedstawionego $\mathrm{w}[2]$.

\section{Wytyczne dla projektowanych pojazdów tram- wajowych na podstawie przeprowadzonych analiz}

W wyniku przeprowadzonych analiz można stwierdzić, że ustalanie optymalnego zarysu pojazdu jest zależne od przyjętej metodyki. W przypadku ustalania dopuszczalnej szerokości pojazdu tramwajowego poprzez obliczanie zwężeń wewnętrznych oraz zewnętrznych, optymalny kształt pojazdu można ustalić poprzez odpowiedni dobór bazy (odległości pomiędzy umownymi środkami obrotu wózków) z warunku:

$$
\mathrm{E}_{\mathrm{i}}=\mathrm{E}_{\mathrm{a}}
$$

W opracowaniu [5] przedstawiono uproszczony ogólny wzór dla pojazdów kolejowych przegubowych wieloczłonowych, który pozwala ustalić optymalną bazę każdego członu pojazdu:

$$
a=\sqrt{12 \cdot E_{a} \cdot R}
$$


Jak widać z przykładu obliczeniowego pojazdu tramwajowego, którego wyniki obliczeń zwężeń wewnętrznych oraz zwężeń zewnętrznych są przedstawione odpowiednio $\mathrm{w}$ tabeli 1 oraz 2, warunek równości obydwu zwężeń nie jest spełniony ( zwężenia zewnętrzne są większe od zwężeń wewnętrznych), co oznacza, że baza pojazdu mogłaby być nieco większa. Podstawiając do wzoru (19) maksymalne zwężenie zewnętrzne wynoszące $\mathrm{E}_{\mathrm{a}}=0,186 \mathrm{~m}$ dla $\mathrm{n}_{\mathrm{a}}=1,5 \mathrm{~m}$, $\mathrm{h}=3,400 \mathrm{~m}$ oraz $\mathrm{R}=20 \mathrm{~m}$ otrzymuje się bazę pojazdu ,a" wynoszącą:

$$
a=\sqrt{12 \cdot 0,186 \cdot 20}=6,68 m
$$

wobec faktycznie przyjętej a=6m. Zwężenie zewnętrzne $E_{a}$ wyznaczone na podstawie przekształconego wzoru (19) dla a=6 m wynosi odpowiednio:

$$
E_{a}=\frac{a^{2}}{12 R}=\frac{6^{2}}{12 \cdot 20}=0,150 \mathrm{~m}
$$

Zakres ważności norm PN-K-92008:1998 [10] wraz PN-K-92008/Ap1 [11] dla baz pojazdów tramwajowych wynoszących $\mathrm{a}_{\max }=8 \mathrm{~m}$ jest uzasadniony. W związku z tym, że wózki ( układy biegowe) charakteryzują się dużym przesuwem poprzecznym $\mathrm{w}_{\mathrm{i}}$ lub $\mathrm{w}_{\mathrm{a}}$ w kierunku wewnętrznym lub zewnętrznym luku toru, warunek ważności potwierdzają również doświadczenia kolejowe, gdzie optymalny zarys członów pojazdów trakcyjnych przystosowanych do wysokich prędkości występuje dla a $\leq 8 \mathrm{~m}$. Wpływ przesuwów poprzecznych na wielkość zwężenia jest $\mathrm{w}$ pojazdach tramwajowych znaczący. Dlatego celowy jest jego optymalny dobór analogicznie jak w pojazdach kolejowych [13].

\section{Wnioski}

Jak wynika $\mathrm{z}$ przedstawionej analizy przemieszczeń geometrycznych na torze prostym oraz na łuku toru, metodyka wyznaczania kinematycznego zapotrzebowania przestrzeni i dopuszczalnego zarysu pojazdu jest zależna od indywidualnego podejścia poszczególnych przedsiębiorstw przewozowych, będących jednocześnie właścicielem infrastruktury oraz taboru tramwajowego.

Przy wyznaczaniu dopuszczalnego zarysu pojazdu tramwajowego należy bardzo dokładnie przeanalizować udział poszczególnych czynników w zwężeniach oraz możliwości konstrukcyjne zmniejszenia ich udziału [2]. Przyjęcie coraz bardziej podatnego usprężynowania pojazdu tramwajowego sprzyja komfortowi jazdy podróżnych, ale $\mathrm{w}$ istotny sposób zwiększa współczynnik pochylania „s”, a tym samym zwężenia quasistatyczne „z”. W związku z powyższym zwężenia zarysu, zwłaszcza w górnych partiach pojazdu, przyjmują bardzo duże wartości.
Spełnienie kryteriów dynamicznych, szczególnie w zakresie dopuszczalnych przyspieszeń działających na pojazd, powinno być wynikiem kompromisu z dopuszczalnym zarysem pojazdu. Takie parametry pojazdu jak szerokość miejsc siedzących, korytarza przejściowego pomiędzy rzędami miejsc siedzących, wysokość podłogi i pojazdu, ilość i usytuowanie drzwi wejściowych ( częstotliwość wsiadania i wysiadania pasażerów) są też cechami określającymi komfort jazdy dla podróżnych.

Celowe jest również udoskonalenie technologii wytwarzania pojazdu tramwajowego, mające na celu ograniczenie odchyłek wykonawczych pojazdu ( $\mathrm{np}$. kąta asymetrii własnej $\theta$ pojazdu tramwajowego) i tym samym mających wpływ na ,kinematyczne zapotrzebowanie przestrzeni." Konstruktor pojazdu powinien posiadać informacje na temat infrastruktury tramwajowej. Wówczas jest możliwość wyznaczania nie tylko dopuszczalnego zarysu pojazdu, ale również kinematycznego zapotrzebowania przestrzeni. Pozwala to na wyznaczenie udziału odpowiednio pojazdu tramwajowego i infrastruktury w tej wielkości i podjęcie odpowiedniej optymalizacji konstrukcji względnie współpracującej z nią infrastruktury.

Jak już sygnalizowano $w$ innych opracowaniach [ $\left[\begin{array}{lll}1 & 1 & 2\end{array}\right]$ metodyka wyznaczania kinematycznego zapotrzebowania przestrzeni przez pojazd pozwala na poznanie wszystkich czynników mających wpływ na przemieszczenia poprzeczne pojazdu, jak również uniknięcie uwzględniania niektórych czynników dwukrotnie.

Oprócz obliczeń analitycznych zaleca się przeprowadzenie analizy graficznej z użyciem wspomagania komputerowego przy użyciu programu AUTO-CAD. Analiza graficzna może być potwierdzeniem poprawności obliczeń zwężeń zarysu odniesienia, zwłaszcza w przypadkach wattpliwych, kiedy kinematyczne zapotrzebowanie przestrzeni może przekroczyć zarys odniesienia skrajni budowli.

\section{Literatura}

[1] Gasowski W., Sobaś M.: Nowoczesna skrajnia pojazdów kolejowych. Instytut Pojazdów Szynowych „, Tabor”. Poznań 2005.

[2] Gasowski W., Sobaś M.: Wyznaczanie dopuszczalnego zarysu pojazdu w oparciu o skrajnie pojazdów szynowych i budowli. Pojazdy Szynowe $\mathrm{Nr} 3 / 2007$.

[3] Krugmann H.L.: Lauf der Schienenfahrzeuge im Gleis. Eine Einführung. R. Oldenbourg Verlag GmbH. München-Wien 1982.

[4] Sobaś M.: Skrajnia kinematyczna i budowli pojazdów tramwajowych. Pojazdy Szynowe $\mathrm{Nr}$ 3/2007.

[5] Pasemann B., Stüwig M., Theile F.: Beitrag zur Einschränkungsberechnung für Gelenkzüge. ZEV +DET Glasers Annalen 122. Nr. 4/1998. 
[6] Tatara F., Sobaś J.: Analiza geometrycznostatyczna biegu pojazdów szynowych w tukach. Wydawnictwo Politechniki Poznańskiej.04.1967. Nr 191.

[7] Karta UIC 505-1: Pojazdy kolejowe. Skrajnia pojazdów. 10-te wydanie z 05.2006.

[8] Karta UIC 505-5: Wspólne warunki podstawowe dla kart 505-1 i 505-4. Komentarz o przygotowaniu tych kart i przepisy ich dotyczqce. 2-gie wydanie $z$ 1.01.1977z aktualnq zmianq $z$ 1.01.1993.

[9] Norma PN-70/K-02056: Tabor kolejowy normalnotorowy. Skrajnie statyczne.

[10] NormaPN-K-92008:1998: Komunikacja miejska. Skrajnia kinematyczna wagonów tramwajowych.

[11] Norma PN-K-92008/Ap1:1998: Komunikacja miejska. Skrajnia kinematyczna wagonów tramwajowych.
[12] Norma PN-K-92009:1998: Komunikacja miejska. Skrajnia budowli. Wymagania.

[13] Raport ERRI B 176/DT 278: Wptyw przemieszczenia poprzecznego belki bujakowej na profile pojazdów.( ang.: „Influence of lateral swing bolster play on vehicle profiles"). Utrecht, maj 1993.

[14] Tymczasowe wytyczne dla określenia zapotrzebowania przestrzeni dla kolei miejskich wg zarzqdzenia dotyczacego budowy $i$ eksploatacji tramwajów (niem. ,Vorläufige Richtlinien für die Bemessung des lichten Raumes nach der Verordnung über den Bau und Betrieb der StraBenbahnen( BOStrab-Lichtraum-Richtlinien"), grudzień 1996.

[15] Wytyczne techniczne projektowania, budowy $i$ utrzymania torów tramwajowych. Ministerstwo Administracji, Gospodarki Terenowej i Ochrony Środowiska. Departament Komunikacji Miejskiej i Dróg. Warszawa 1983. 